\title{
Effect of Hyaluronic Acid on Organogenesis in Rhizome Cultures of Cymbidium kanran Makino
}

\section{Mohammad Mostafa Kamal, Kazuhiko Shimasaki ${ }^{1}$ and Nasren Akter ${ }^{2}$}

The United Graduate School of Agricultural Sciences, Ehime University, 3-5-7 Tarumi, Matsuyama, Ehime, 790-8556 Japan

Key words: Terrestrial Cymbidium, Rhizome, Hyaluronic acid, Shoot formation

The effects of adding two types of hyaluronic acid with different molecular weights (HA9, M.W. 8 - 11.7 KDa; HA12, M.W. 11 - 16 KDa; Shiseido Co. Ltd., Japan), to modified MS on organogenesis in rhizome-tip cultures of Cymbidium kanran was investigated and compared with adding BA and NAA. HA9 was most effective in inducing shoot formation. The results suggested that HA9 is effective for rhizome and shoot formation. HA12 is effective for rhizome-like shoot formation. BA and NAA did not have a significant effect on regulating organogenesis in this species. It was demonstrated that HA9 and HA12 could be used as plant growth regulators for rhizome-tip cultures of a terrestrial Cymbidium species.

Cymbidium kanran is a terrestrial species and known as a temperate species which is difficult to propagate (Shimasaki and Uemoto 1990). Several studies have reported cytokinin-induced shoot formation in rhizome cultures of $C$. kanran and closely related species (Hasegawa et al. 1985, Hasegawa and Goi 1987, Kokubu et al. 1980, Lee and So 1985, 1988, Lee 1988.).

We investigated the effect of hyaluronic acid with different molecular weights (HA9 and HA12, Shiseido, Japan) on organogenesis in rhizomes of Cymbidium kanran cultures in vitro and compared it with BA and NAA supplemented with modified MS.

C. kanran rhizome proliferated in modified MS excised rhizome apical segments (ca. $5 \mathrm{~mm}$ in length), served as explants. UM culture bottles $(250 \mathrm{ml})$ containing $30 \mathrm{ml}$ of medium were used in the experiments. Fifteen rhizome segments were cultured in each treatment. Cultures were maintained at $25 \pm 1^{\circ} \mathrm{C}$

${ }^{1}$ Faculty of Agriculture, Kochi University, Otsu 200 Monobe, Nankoku, Kochi, 783-8502, Japan. ${ }^{2}$ National University, Board Bazar, Gazipur 1704, Bangladesh. 
under white fluorescent light at $25 \mu \mathrm{E} / \mathrm{m} 2 / \mathrm{s}$ for a $16 \mathrm{hrs}$ photoperiod for 8 weeks. Experimental data were collected after 8 weeks.

The effect of HA9 on rhizome growth and shoot formation is shown in Table 1 and Fig. 1A. The highest rate of rhizome branch formation was $93.3 \%$ and the maximum rhizome number (3.4) was recorded in the medium containing 0.01 $\mathrm{mg} / \mathrm{l} \mathrm{HA9}$. Adding HA9 0.1 and $1 \mathrm{mg} / \mathrm{l}$ resulted in the highest number of shoots (53.3\%). The effect of HA12 on organogenesis in rhizomes is shown in Table 2. and Fig. 1B. The highest rate of rhizome branch formation was $73.3 \%$ and the maximum rhizome number (3.4) was recorded in the medium containing 0.01 $\mathrm{mg} / \mathrm{l}, 0.1 \mathrm{mg} / \mathrm{l}$, and $1 \mathrm{mg} / \mathrm{l} \mathrm{HA} 12$. The shoot formation was $(30 \%)$ and shoot number (0.4) for the control treatment. The effect of BA and NAA on rhizome and shoot branch formation is shown in Table 3 and Fig. 1C. The media supplemented with BA and NAA showed the maximum number of rhizomes

Table 1. Effect of HA9 on organogenesis in rhizome culture of $C$. kanran after 8 weeks.

\begin{tabular}{|c|c|c|c|c|c|c|c|c|}
\hline \multirow[t]{2}{*}{$\begin{array}{l}\text { HA9 } \\
(\mathrm{mg} / \mathrm{l})\end{array}$} & \multicolumn{2}{|c|}{ Rhizome } & \multicolumn{2}{|l|}{$\begin{array}{l}\text { Shoot-like } \\
\text { rhizome }\end{array}$} & \multicolumn{2}{|l|}{ Shoot } & \multicolumn{2}{|c|}{$\begin{array}{l}\text { Rhizome-like } \\
\text { shoot }\end{array}$} \\
\hline & $\begin{array}{l}\text { Average } \\
\text { number }\end{array}$ & $\begin{array}{l}\text { Form. } \\
\text { rate }(\%)\end{array}$ & $\begin{array}{l}\text { Average } \\
\text { number }\end{array}$ & $\begin{array}{l}\text { Form. } \\
\text { rate }(\%)\end{array}$ & $\begin{array}{l}\text { Average } \\
\text { number }\end{array}$ & $\begin{array}{l}\text { Form. } \\
\text { rate }(\%)\end{array}$ & $\begin{array}{l}\text { Average } \\
\text { number }\end{array}$ & $\begin{array}{l}\text { Form. } \\
\text { rate }(\%)\end{array}$ \\
\hline 0 & $1.7 \pm 0.5$ & 50.0 & $0.2 \pm 0.1$ & 10.0 & $0.4 \pm 0.1$ & 30.0 & $1.2 \pm 0.5$ & 50.0 \\
\hline 0.01 & $3.4 \pm 0.3$ & 93.3 & $1.6 \pm 0.2$ & 86.6 & $0.6 \pm 0.2$ & 40.0 & $3.4 \pm 0.4$ & 93.3 \\
\hline 0.1 & $2.9 \pm 0.6$ & 80.0 & $1.7 \pm 0.3$ & 80.0 & $0.5 \pm 0.1$ & 53.3 & $2.6 \pm 0.4$ & 86.6 \\
\hline 1 & $3.2 \pm 0.6$ & 80.0 & $1.7 \pm 0.4$ & 80.0 & $0.5 \pm 0.1$ & 53.3 & $3.0 \pm 0.8$ & 80.0 \\
\hline 10 & $1.6 \pm 0.4$ & 73.3 & $1.1 \pm 0.2$ & 80.0 & $0.6 \pm 0.4$ & 33.3 & $1.5 \pm 0.3$ & 80.0 \\
\hline
\end{tabular}

Values represent means \pm S.E. The cultures were examined after 8 weeks. Each treatment consisted of 3 replicates, and each replicate consisted of 5 rhizomes.
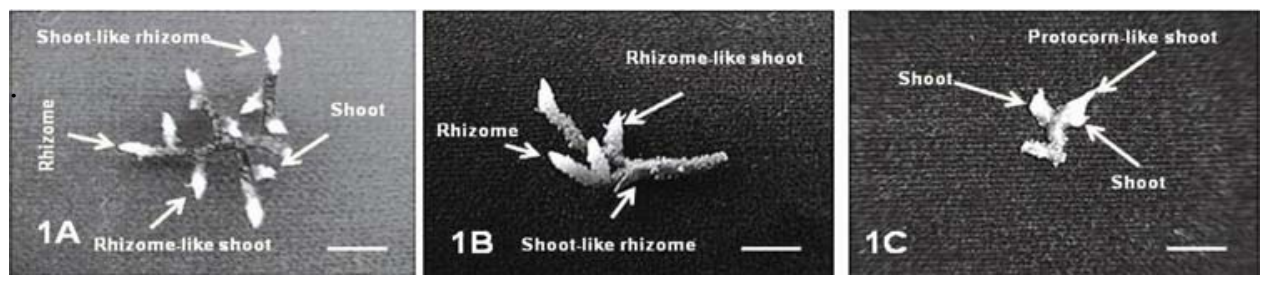

Fig. 1. The effect of HA9, HA12 and combination of BA and NAA on organogenesis in rhizome cultures 1A : HA9 $0.01 \mathrm{mg} / \mathrm{l}, 1 \mathrm{~B}:$ HA12 $0.01 \mathrm{mg} / \mathrm{l}$ and 1C: BA 0.1mg/l + NAA $0.1 \mathrm{mg} / \mathrm{l}$. (Bars $=10 \mathrm{~mm}$ ).

(60\%) and the maximum rhizome number (1.7) was obtained at $1 \mathrm{mg} / \mathrm{l} \mathrm{BA}, 0.1$ $\mathrm{mg} / \mathrm{l} \mathrm{NAA}, 0.1 \mathrm{mg} / \mathrm{l} \mathrm{BA}+0.1 \mathrm{mg} / \mathrm{l} \mathrm{NAA}$, and $1 \mathrm{mg} / \mathrm{lBA}+0.1 \mathrm{mg} / \mathrm{l} \mathrm{NAA}$. The maximum shoot formation (46.6\%) and the maximum number of shoots (0.9) was recorded in the combined treatment of $0.1 \mathrm{mg} / 1 \mathrm{BA}$ and $0.1 \mathrm{mg} / \mathrm{l} \mathrm{NAA}$. 
The rate of formation of rhizome branches, shoots, shoot-like rhizomes and rhizome-like shoots was higher in HA9 than HA12 or the combined application of BA and NAA. These results indicate that HA9 can stimulate rhizome induction. Low molecular weight HA9 was more effective for growth promotion than that of higher one.

Table 2. Effect of HA 12 on organogenesis in rhizome culture of C. kanran after 8 weeks.

\begin{tabular}{|c|c|c|c|c|c|c|c|c|}
\hline \multirow{2}{*}{$\begin{array}{l}\text { HA } 12 \\
(\mathrm{mg} / \mathrm{l})\end{array}$} & \multicolumn{2}{|c|}{ Rhizome } & \multicolumn{2}{|c|}{ Shoot-like rhizome } & \multicolumn{2}{|l|}{ Shoot } & \multicolumn{2}{|c|}{ Rhizome-like shoot } \\
\hline & $\begin{array}{l}\text { Average } \\
\text { number }\end{array}$ & $\begin{array}{l}\text { Form. } \\
\text { rate } \\
(\%)\end{array}$ & $\begin{array}{l}\text { Average } \\
\text { number }\end{array}$ & $\begin{array}{l}\text { Form. } \\
\text { rate (\%) }\end{array}$ & $\begin{array}{l}\text { Average } \\
\text { number }\end{array}$ & $\begin{array}{l}\text { Form. } \\
\text { rate } \\
(\%)\end{array}$ & $\begin{array}{l}\text { Average } \\
\text { number }\end{array}$ & $\begin{array}{l}\text { Form. } \\
\text { rate }(\%)\end{array}$ \\
\hline 0 & $1.7 \pm 0.5$ & 50.0 & $0.2 \pm 0.1$ & 10.0 & $0.4 \pm 0.1$ & 30.0 & $1.2 \pm 0.5$ & 50.0 \\
\hline 0.01 & $3.4 \pm 0.9$ & 73.3 & $0.7 \pm 0.1$ & 60.0 & $0.2 \pm 0.1$ & 26.6 & $2.5 \pm 0.6$ & 60.0 \\
\hline 0.1 & $1.5 \pm 0.3$ & 73.3 & $0.6 \pm 0.2$ & 46.6 & $0.1 \pm 0.1$ & 13.3 & $1 \pm 0.2$ & 60.0 \\
\hline 1 & $1.8 \pm 0.3$ & 73.3 & $0.7 \pm 0.1$ & 60.0 & $0.2 \pm 0.1$ & 13.3 & $1.1 \pm 0.2$ & 66.6 \\
\hline 10 & $1.4 \pm 0.6$ & 50.0 & $0.4 \pm 0.2$ & 20.0 & $0.1 \pm 0.1$ & 10.0 & $1.2 \pm 0.5$ & 40.0 \\
\hline
\end{tabular}

Values represent means \pm S.E. The cultures were examined after 8 weeks. Each treatment consisted of 3 replicates, and each replicate consisted of 5 rhizomes.

Table 3. Effect of BA and NAA added to MS on rhizome and shoot formation rhizome culture of $C$. kanran after 8 weeks.

\begin{tabular}{|c|c|c|c|c|c|c|c|c|c|}
\hline \multicolumn{2}{|c|}{$\begin{array}{l}\text { Treatments } \\
(\mathrm{mg} / \mathrm{l})\end{array}$} & \multicolumn{2}{|c|}{ Rhizome } & \multicolumn{2}{|c|}{$\begin{array}{l}\text { Shoot-like } \\
\text { rhizome }\end{array}$} & \multicolumn{2}{|c|}{ Shoot } & \multicolumn{2}{|c|}{$\begin{array}{c}\text { Rhizome-like } \\
\text { shoot }\end{array}$} \\
\hline $\mathrm{BA}$ & NAA & $\begin{array}{l}\text { Average } \\
\text { number }\end{array}$ & $\begin{array}{l}\text { Rate } \\
(\%)\end{array}$ & $\begin{array}{l}\text { Average } \\
\text { number }\end{array}$ & $\begin{array}{l}\text { rate } \\
(\%)\end{array}$ & $\begin{array}{l}\text { Average } \\
\text { number }\end{array}$ & $\begin{array}{l}\text { rate } \\
(\%)\end{array}$ & $\begin{array}{l}\text { Average } \\
\text { number }\end{array}$ & $\begin{array}{l}\text { rate } \\
(\%)\end{array}$ \\
\hline 0 & 0 & $1.7 \pm 0.5$ & 50.0 & $0.2 \pm 0.1$ & 10.0 & $0.4 \pm 0.1$ & 30.0 & $1.2 \pm 0.5$ & 50.0 \\
\hline 0.1 & 0 & $0.7 \pm 0.1$ & 53.3 & $0.4 \pm 0.1$ & 40.0 & 0 & 0.0 & $0.2 \pm 0.1$ & 20.0 \\
\hline 1 & 0 & $1.0 \pm 0.3$ & 60.0 & $0.4 \pm 0.1$ & 40.0 & $0.9 \pm 0.4$ & 33.3 & $0.2 \pm 0.1$ & 26.6 \\
\hline 0 & 0.1 & $0.8 \pm 0.2$ & 60.0 & $0.4 \pm 0.2$ & 33.3 & 0 & 0.0 & $0.4 \pm 0.1$ & 33.3 \\
\hline 0.1 & 0.1 & $1.6 \pm 0.5$ & 60.0 & $0.6 \pm 0.2$ & 40.0 & $0.8 \pm 0.2$ & 46.6 & $0.6 \pm 0.2$ & 26.6 \\
\hline 1 & 0.1 & $1.0 \pm 0.2$ & 60.0 & $0.7 \pm 0.1$ & 60.0 & $0.8 \pm 0.3$ & 40.0 & $0.4 \pm 0.1$ & 40.0 \\
\hline 0 & 1 & $0.8 \pm 0.3$ & 46.6 & $0.6 \pm 0.2$ & 40.0 & 0 & 0.0 & $0.2 \pm 0.1$ & 13.3 \\
\hline 0.1 & 1 & $0.7 \pm 0.2$ & 46.6 & $0.3 \pm 0.1$ & 26.6 & $0.6 \pm 0.3$ & 20.0 & $0.4 \pm 0.1$ & 33.3 \\
\hline 1 & 1 & $1.0 \pm 0.3$ & 46.6 & $0.4 \pm 0.1$ & 40.0 & $0.4 \pm 0.1$ & 26.6 & $0.3 \pm 0.1$ & 33.3 \\
\hline
\end{tabular}

Values represent means \pm S.E. The cultures were examined after 8 weeks. Each treatment consisted of 3 replicates, and each replicate consisted of 5 rhizomes.

In terrestrial Cymbidium cultures, higher concentrations of BA added to culture medium promote shoot formation (Shimasaki and Uemoto 1990). Nahar et al. (2011) showed hyaluronic acid can be applied to epiphytic Cymbidium species. Present results suggest that HA9 and HA12 can be used as a growth 
regulator for terrestrial Cymbidium cultures. Chitosan added to culture media promotes organogenesis in Cymbidium species (Shimasaki et al. 2003). Our results show that hyaluronic acid can be used as a new plant growth regulator for terrestrial in vitro culture of Cymbidium.

\section{References}

Hasegawa A and Goi M (1987) Rhizome formation in Cymbidium goeringii Reichenbach fil, and Cymbidium kanran Makino in shoot-tip culture. J. Japan Hortic. Sci. 56:70-78.

Hasegawa A, Ohashi H and Goi M (1985) Effect of BA on rhizome length, mechanical and liquid shaking culture on the shoot formation from rhizome in Cymbidium faberi Rolfe. Acta Hortic. 166:25-40.

Kokubu T, Kaieda Y, Higashi Y, Kitano T and Fukamizu K (1980) Organogenesis in sterile culture of oriental Cymbidium, Cymbidium kanran Makino. Mem. Fac. Agric. Kagoshima Univ. 16: 53-64.

Lee Js and So Is (1985) Effect of NAA and BA on dark culture of Cymbidium virescences rhizome in vitro. Subtrop. Agric. Cheju Nat. Univ. 2: 133-139.

Lee Js and So Is (1988) Effect of NAA, BA and temperature on growth and shoot differentiation of Cymbidium neveo-marginatum Makino rhizome in vitro. Cheju Nat. Univ. J. 27: 21-27.

Lee Js (1988) Study on rhizome culture of the inter-specific hybrid of oriental Cymbidiums in vitro. Subtrop. Agric. Cheju Nat. Univ. 5: 49-59.

Nahar SJ, Shimasaki K, Huang CL and Naruemol K (2011) Effect of plant growth regulators on organogenesis in protocorn-like body (PLBs) of Cymbidium dayanum in vitro. ARPN J. Agril. Biol. Sci. 6(6):28-33.

Shimasaki K and Uemoto S (1990) Micropropagation of a terrestrial Cymbidium species using rhizomes developed from seeds and pseudobulbs. Plant Cell, Tiss. Org. Cult. 22: $237-244$.

Shimasaki K, Tanibuchi $\mathbf{Y}$ and Fukumoto $\mathbf{Y}$ (2003) The effects of chitosan on organogenesis in protocorm-like body (PLB) of Cymbidium finleysonianum Lindl. J. Soc. High. Tech. Agric. 15(2):90-93. 